Jurnal Pemberdayaan: Publikasi Hasil Pengabdian kepada Masyarakat

Vol. 2, No. 2, Agustus 2018, Hal. 375-380

ISSN: 2088 4559; e-ISSN: XXXX-XXXX

DOI:

\title{
PEMBERDAYAAN KELOMPOK WANITA TANI DALAM DIVERSIFIKASI OLAHAN IKAN NILA
}

\author{
Diah Asta Putri ${ }^{1}$, Ambar Pratiwi2, Nurul Suwartiningsih ${ }^{3}$ \\ ${ }^{1,2,3}$ Universitas Ahmad Dahlan, Jl. Ringroad Selatan, Tamanan, Banguntapan, Bantul \\ Email: diah.putri@bio.uad.ac.id
}

\begin{abstract}
ABSTRAK
Masyarakat di wilayah PRA Ambarketawang dan Kelompok Wanita Tani (KWT) An-Naba' Gamping Sleman melakukan budidaya ikan nila namun dalam pemasaran masih berupa ikan mentah. Tim pengabdian bermaksud memberikan penyuluhan, pelatihan serta pendampingan dalam diversifikasi pengolahan ikan nila. Kegiatan ini sebagai upaya pemenuhan kebutuhan protein hewani untuk konsumsi sehari-hari dari bahan yang dibudidaya oleh masyarakat setempat. Kegiatan ini juga dapat bermanfaat dalam meningkatkan daya jual ikan nila dan menambah pendapatan. Kegiatan dilaksanakan dalam beberapa sesi meliputi penyuluhan tentang manfaat, kandungan gizi serta potensi ikan nila, pelatihan pembuatan nugget, pelatihan pembuatan mie, pelatihan pembuatan stik, pelatihan pembuatan bakso, pelatihan pengemasan produk dan pemasaran produk. Kesimpulan kegiatan pengabdian ini yaitu adanya motivasi untuk mengembangkan potensi desa dengan meningkatnya pengetahuan dan keterampilan mitra dalam mengolah ikan nila menjadi produk berupa nugget ikan, stik ikan, mie ikan dan bakso ikan serta meningkatnya pengetahuan mitra dalam pengemasan produk dengan aman dan menarik agar dapat bersaing dengan produk sejenis lainnya.
\end{abstract}

Kata kunci: ikan nila, nugget, bakso, mie, stik ikan

\begin{abstract}
Communities in the area of PRA Ambarketawang and KWT An-Naba' Gamping Sleman Yogyakarta conduct tilapia fish cultivation. But, they usually sell tilapia fish to the market in raw condition. Therefore, we intends to provide counseling, training and assistance in diversifying the processing of tilapia fish. This activity is an effort to fulfill the needs of protein for daily consumption from ingredients cultivated by the local community. This activity can also be useful in increasing the selling power of tilapia fish and increasing income. The activities carried out in several sessions included counseling on the benefits, nutritional content and potential of tilapia, training in making nuggets, noodles, fish sticks, meatballs, training on product packaging and product marketing. The conclusion of this service activity is the increasing knowledge and skills of partners in processing tilapia into products in the form of fish nuggets, fish sticks, fish noodles and fish meatballs and increasing partners knowledge in packaging products safely and attractively in order to compete with other similar products.
\end{abstract}

Keywords: tilapia, nugget, meatball, noodle, fish stick 


\section{PENDAHULUAN}

Ikan nila termasuk komoditas yang banyak dikembangkan dikarenakan permintaan pasar yang cukup tinggi, rasa dagingnya yang enak, harga yang relatif stabil serta pemeliharaannya yang mudah. Ikan nila mudah beradaptasi sehingga bisa memakan segala bahan makanan yang berada di depannya dan termasuk ikan golongan omnivora (Ciptano, 2010). Protein dalam tubuh ikan merupakan senyawa yang kandungannya paling tinggi setelah air. Protein memegang peranan penting dalam struktur dan fungsi tubuh, seperti pertumbuhan dan reproduksi. Hasil penelitian Ramlah dkk (2016) menunjukkan dalam 100 gram ikan nila mempunyai kandungan protein 16,79 g, kandungan karbohidrat 0,32 g, kandungan lemak 0,18 g, kandungan kalsium 4,782 mg, kandungan fosfor $610 \mathrm{mg}$, dan kandungan zat besi $0,835 \mathrm{mg}$.

Peran dan partisipasi kaum wanita dalam pembangunan bisa diwujudkan melalui peran dan partisipasi wanita dalam Kelompok Wanita Tani (KWT). Diharapkan kelompok wanita mampu meningkatkan tingkat ekonomi masyarakat dengan mendirikan usaha/industri yang bergerak di bidang pengolahan makanan dengan mengutamakan produk lokal sebagai produk utama dari usaha/industri.

Kelompok Wanita Tani (KWT) An-Naba berlokasi di Padukuhan Gamping Lor, Desa Ambarketawang, Kecamatan Gamping, Sleman di lingkungan PRA Ambarketawang. KWT ini berfokus mengolah produk lokal menjadi produk olahan. Beberapa produk yang dihasilkan dari KWT An-Naba' antara lain jahe instan, tepung cassava dan tepung mocaf. Kegiatan KWT An-Naba' didukung dengan partisipasi anggota terhadap kegiatan seperti 1) Pertemuan anggota yang merupakan kegiatan pertemuan antar anggota yang diadakan oleh KWT An-Naba' 2) Pemasaran yang merupakan kegiatan yang dilakukan oleh anggota KWT An-Naba' untuk menjual produk-produk yang dihasilkan oleh KWT An-Naba' 3) Produksi yang merupakan pembuatan produk-produk oleh KWT An-Naba' 4) Kegiatan simpan pinjam yang merupakan kegiatan simpan (menabung) uang dan meminjam uang yang dilaksanakan oleh KWT An-Naba'.

Lahan perikanan yang dikembangkan oleh KWT An-Naba' berada di area Ambarketawang di dusun Gamping Lor dan Mejing Kidul. Area ini di aliri oleh sungai Bedog sehingga ketersediaan air bersih terpenuhi untuk budidaya nila. Potensi perikanan yang dikembangkan di Gamping lor antara lain ikan nila, bawal, gurame. Tetapi mayoritas yang dikembangkan adalah perikanan nila. Sepanjang 1 hektar lahan di Gamping Lor terdiri 
dari 20-24 kolam yang digunakan untuk budidaya. Nila dipanen 3-4 bulan dengan hasil panen mencapai $100-200 \mathrm{~kg}$.

Salah satu cara untuk membantu meningkatkan daya jual ikan nila yang dikelola oleh KWT adalah dengan mengolahnya menjadi berbagai macam olahan yang memiliki nilai ekonomi lebih tinggi seperti nugget, stik, mie dan bakso. Pengemasan yang menarik dari produk juga diperlukan untuk meningkatkan daya saing. Peningkatan keterampilan masyarakat melalui pelatihan pengolahan produk ikan nila ini diharapkan mampu mendorong kemajuan perekonomian anggota KWT An-Naba'.

\section{METODE}

Metode pelaksanaan kegiatan pengabdian yaitu melalui penyuluhan dan pelatihan. Penyuluhan ini merupakan cara untuk menyampaikan pengetahuan kepada anggota KWT An-Naba' tentang manfaat, kandungan gizi serta potensi ikan nila. Tujuan dari kegiatan penyuluhan ini berupa meningkatnya pengetahuan anggota KWT An-Naba' tentang manfaat, kandungan gizi serta potensi ikan nila.

Pelatihan pembuatan nugget, stik, mie, bakso dimaksudkan untuk meningkatkan nilai jual ikan nila dari bahan mentah menjadi produk olahan.

Pelatihan pengemasan produk dan pemasaran produk merupakan solusi dari daya simpan produk olahan (nugget, mie, stik dan bakso) yang berbeda-beda. Selain itu pengemasan produk merupakan salah satu daya tarik konsumen yang akan mempengaruhi nilai jual. Luaran dari pelatihan ini berupa produk olahan yang dikemas dengan baik dan menarik.

\section{HASIL, PEMBAHASAN, DAN DAMPAK}

Kegiatan pengabdian ini mendapat respon yang sangat baik. Peserta antusias mengikuti penyuluhan dan pelatihan yang dilaksanakan dalam beberapa sesi pertemuan. Antusiame tersebut terlihat dari aktifnya peserta dalam bertanya kepada narasumber penyuluhan serta mengikuti tahap-tahap pelatihan. Hasil dari beberapa tahapan pelaksanaan kegiatan pengabdian ini yaitu sebagai berikut:

1. Meningkatnya pengetahuan mitra mengenai diversifikasi olahan ikan nila. Sebelum kegiatan pengabdian dilaksanakan, mitra hanya menjual ikan nila dalam bentuk utuhnya tanpa diolah menjadi produk yang nilai jualnya lebih tinggi. Oleh karena itu kegiatan perdana yang dilakukan adalah transfer informasi mengenai kandungan gizi 
dan potensi ikan nila. Hasilnya mitra menyadari pentingnya diversifikasi olahan ikan nila dan termotivasi untuk memberikan nilai tambah pada ikan nila.

2. Meningkatnya keterampilan mitra dalam menolah ikan nila menjadi produk olahan yang enak, awet dan bernilai jual serta dikemas baik. Pada kegiatan pelatihan dan pendampingan dalam pengolahan ikan nila ini mitra didampingi oleh narasumber dari tim pengusul pengabdian sesuai dengan bidang keahliannya. Pelatihan dilakukan dalam lima pertemuan hingga mitra dapat secara mandiri memproduksi berbagai olahan ikan nila yaitu mie, stik, nugget dan bakso. Olahan ikan nila produksi KWT An-Naba' ini diberi nama ONIK yang merupakan kependekan dari Olahan Nila Organik. Dalam pelatihan ini tim pengusul menyokong modal awal berupa mesin pencacah daging dan mesin pencetak mie. Setelah produk dikemas dengan baik, mitra diberikan pelatihan mengenai strategi pemasaran. Tujuannya agar mitra mampu bersaing dengan produk sejenis sehingga akan meningkatkan pendapatan mitra.
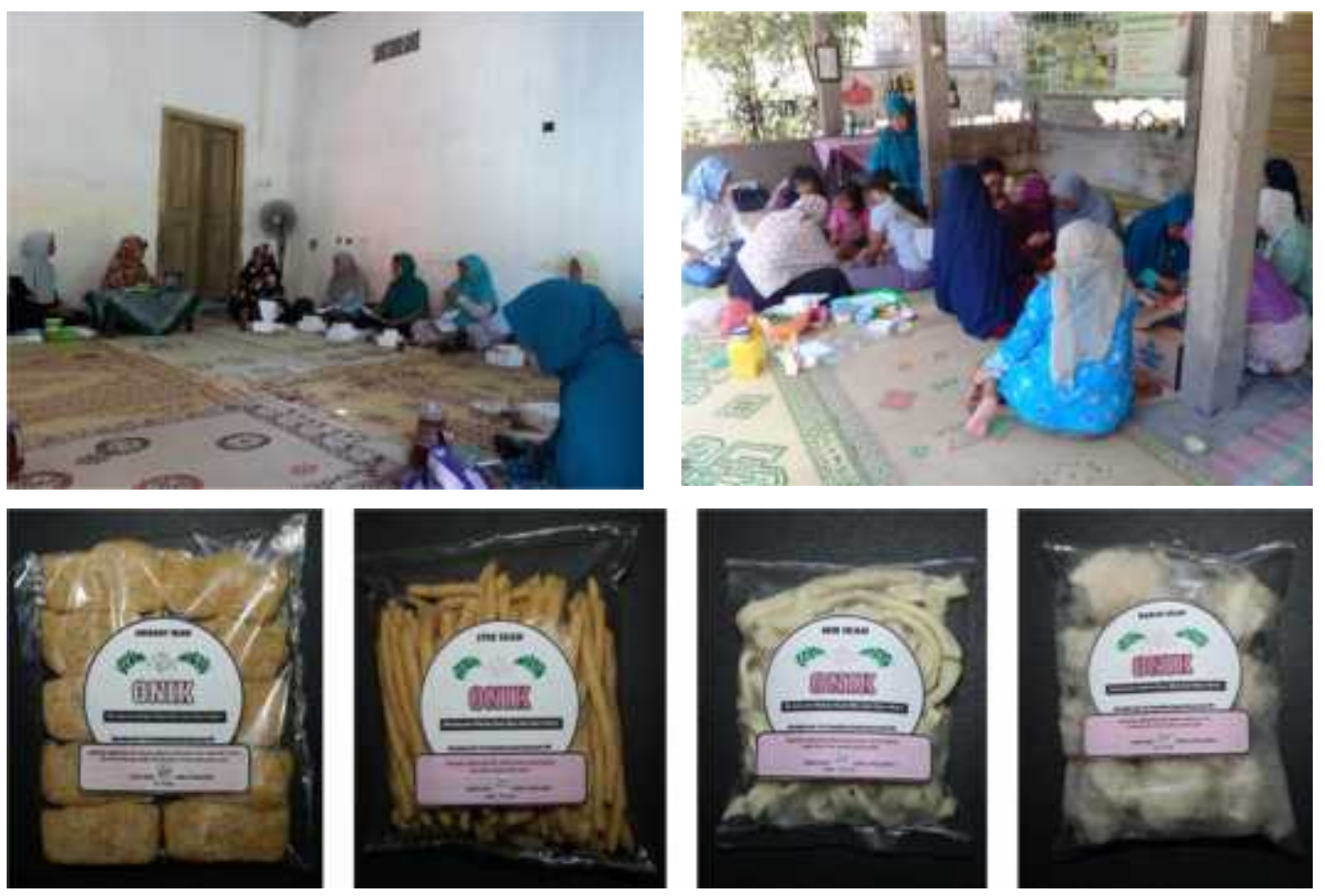

Gambar 1. Penyuluhan, pelatihan dan produk olahan ikan nila yang telah dikemas.

\section{SIMPULAN}

Kesimpulan kegiatan pengabdian ini yaitu meningkatnya pengetahuan dan keterampilan mitra dalam mengolah ikan nila menjadi produk berupa nugget ikan, stik ikan, mie ikan dan bakso ikan serta meningkatnya pengetahuan mitra dalam pengemasan produk 
dengan aman dan menarik agar dapat bersaing dengan produk sejenis lainnya. Saran yang dapat diberikan yaitu perlu dilakukan pelatihan selanjutnya tentang proses memperoleh ijin penjualan produk dari BPOM sehingga dapat meningkatkan kepercayaan masyarakat terhadap produk olahan ikan yang diproduksi oleh KWT An-Naba'.

\section{DAFTAR PUSTAKA}

Ciptanto, S. (2010) Top 10 Ikan Air Tawar Panduan Lengkap Pembesaran Secara Organik di Kolam Air, Kolam Terpal, Karamba, dan Jala Apung. Lily Publisher. Yogyakarta.

Ramlah, Eddy S., dan Zohrah H. (2016) Perbandingan Kandungan Gizi Ikan Nila Oreochromis niloticus Asal Danau Mawang Kabupaten Gowa Dan Danau Universitas Hasanuddin Kota Makassar. http://repository.unhas.ac.id/JURNAL/Ramlah. Diakses tanggal 28 Juni 2018. 
